\title{
KING-ARMSTRONG PHOSPHATASE ESTIMATION BY THE DETERMINATION OF LIBERATED PHOSPHATE*
}

\author{
BY \\ E. J. KING, M. A. M. ABUL-FADL, AND P. G. WALKER \\ From the Postgraduate Medical School, London
}

(RECEIVED FOR PUBLICATION MAY 25, 1950)

As a result of many requests for a phosphatase method which would use the phenyl phosphate substrate of King and Armstrong (1934), but which would substitute a determination of the liberated inorganic phosphate for that of phenol, we have developed two procedures which are described in this paper. The principal reason for a method in which the final measurement is of inorganic phosphate is that an estimation of the plasma phosphate is often required in the study of children's diseases; and it is thought to be desirable to combine this estimation with the phosphatase determination, as may easily be done by making the inorganic phosphate estimation identical with the control for the phosphatase. This is done in some of the glycerophosphate procedures, such as those of Jenner and Kay (1932) and Bodansky (1933). But the use of phenol phosphate for phosphatase determination is greatly to be preferred, because of the greater convenience of the procedure, the much shorter time which is necessary to complete the determination, and the small amounts of blood plasma or serum required.

Two procedures are set out below: in one the determination of liberated phosphate is by the molybdate method of Fiske and Subbarow (1925) with aminonaphtholsulphonic acid as reducing agent; in the other, a more micro procedure, a molybdatestannous chloride method is used. Both procedures employ the same substrate, buffer, temperature, and hydrolysis time as the phenyl phosphate method in which phenol is determined, so that the conditions are identical with those of the KingArmstrong method as modified by King (1951). The results are identical in theory, since one molecule each of phenol and phosphate are liberated for each molecule of phenyl phosphate hydrolysed, and the comparisons of results obtained by the different procedures has, in fact, shown them to be in excellent agreement.

\section{Methods}

Substrate.-This is $0.01 \mathrm{M}$-disodium phenyl phosphate prepared by dissolving $2.18 \mathrm{~g}$. in 1 litre of distilled water which is heated quickly to the boil to destroy any micro-organisms, and preserved in the ice-box, with a few drops of chloroform added as an antiseptic. $\dagger$

\footnotetext{
* The procedures described in this paper were demonstrated to the Biochemical Society and an abstract published in the Biochtmical Journal (1950, 46, xxiv).

+ If the disodium phenylphosphate contains appreciable inorganic phosphate the solid material should be extracted with $95 \%$ alcohol in a Soxhlet.
} 
Buffer $(p \mathrm{H}$ 10).-This buffer is 0.1 M-sodium carbonate-bicarbonate $\left(6 \mathrm{Na}_{2} \mathrm{CO}_{3}: 4 \mathrm{NaHCO}_{3}\right)$ prepared by dissolving $6.36 \mathrm{~g}$. $\mathrm{Na}_{2} \mathrm{CO}_{3}$ (anhydrous) and $3.36 \mathrm{~g}$. $\mathrm{NaHCO}_{3}$ in distilled water and diluting to 1 litre.

Buffer ( $p \mathrm{H} 4.9)$. - The second buffer is $0.2 \mathrm{M}$-sodium acetate-acetic acid (6.5 NaOAc : $3.5 \mathrm{HOAc})$ prepared by adding $65 \mathrm{ml} .0 .2 \mathrm{M}$-sodium acetate $\left(27.2 \mathrm{~g}\right.$. $\mathrm{C}_{2} \mathrm{H}_{3} \mathrm{O}_{2} \mathrm{Na}_{3} 3 \mathrm{H}_{2} \mathrm{O}$ per litre) to $35 \mathrm{ml} .0 .2 \mathrm{M}$-acetic acid (11.3 ml. pure glacial acetic acid per litre).

Trichloroacetic Acid. $-7 \%$ and $20 \%$.

Molybdate.-Ammonium molybdate, $5 \mathrm{~g}$., dissolved in $100 \mathrm{ml}$. of approximately 5 $\mathrm{N}-\mathrm{H}_{2} \mathrm{SO}_{4}$ prepared by adding $14 \mathrm{ml}$. concentrated sulphuric acid, slowly and with stirring, to $86 \mathrm{ml}$. of distilled water.

Aminonaphtholsulphonic Acid Reducing Agent.-1:2:4-Aminonaphtholsulphonic acid, 0.2 g., sodium metabisulphite, $12 \mathrm{~g}$., and crystalline sodium sulphite $\left(\mathrm{Na}_{2} \mathrm{SO}_{3} .7 \mathrm{H}_{2} \mathrm{O}\right)$, $2.4 \mathrm{~g}$., are dissolved in $100 \mathrm{ml}$. of distilled water.

Stannous Chloride Reducing Agent.-This is a stock solution prepared monthly and kept in the ice-chest. Stannous chloride $\left(\mathrm{SnCl}_{2}\right) 10 \mathrm{~g}$. is dissolved in $100 \mathrm{ml}$. of approximately $5 \mathrm{~N}-\mathrm{HCl}$ (1 : 1 dilution of concentrated reagent hydrochloric acid with distilled water). The reducing agent is a 1 in 20 dilution of the stock solution with $5 \mathrm{~N}-\mathrm{H}_{2} \mathrm{SO}_{4}$, prepared fresh daily.

Stock Standard Phosphate.-Potassium dihydrogen phosphate (pure, A.R.), 2.194 g., is dissolved in distilled water in a 500-ml. flask, made up to the mark, and mixed. A few drops of chloroform should be added to prevent growth of micro-organisms. This solution contains $1.0 \mathrm{mg}$. phosphorus per $\mathrm{ml}$.

Standard Phosphate Solution $(0.004 \mathrm{mg}$. $\mathrm{P}$ in $1 \mathrm{ml}$.).-A quantity, $2.0 \mathrm{ml}$., of the stock standard phosphate is accurately measured into a $500-\mathrm{ml}$. volumetric flask, diluted to the mark with distilled water, well mixed, and preserved with a few drops of chloroform.

\section{Alkaline Phosphatase: Method I*}

Test.-Buffer and substrate, $3 \mathrm{ml}$. of each, are pipetted into a test-tube and warmed in a thermostat water bath at $37^{\circ} \mathrm{C}$. for three or four minutes. Plasma or serum, $0.3 \mathrm{ml}$., is added, the tube stoppered, gently shaken, and left in the bath for exactly 15 minutes. The tube is removed, and $1.2 \mathrm{ml}$. of $20 \%$ trichloroacetic acid quickly added to stop the hydrolysis. The mixture is shaken and filtered or centrifuged clear of precipitated proteins.

Control.-Plasma, $0.3 \mathrm{ml}$., is added to $6 \mathrm{ml}$. of water, mixed with $1.2 \mathrm{ml}$. of $20 \%$ trichloroacetic acid, and filtered.

Blank.-Buffer, $3 \mathrm{ml}$., and $3 \mathrm{ml}$. of substrate are mixed with $0.3 \mathrm{ml}$. of water and $1.2 \mathrm{ml}$. of $20 \%$ trichloroacetic acid.

Phosphate Determinations.-To $5 \mathrm{ml}$. each of the test, control and blank, and of the standard phosphate solution ( $\equiv 0.02 \mathrm{mg}$. P), are added $0.8 \mathrm{ml}$. of the molybdate and $0.2 \mathrm{ml}$. of the aminonaphtholsulphonic acid reducing agent. The tubes are mixed, and ten minutes allowed for the blue colours to develop, and the reading (extinction) of each is then determined in a photo-electric colorimeter fitted with a red light filter; alternatively the test, control, and blank are read against the standard in a Duboscq colorimeter (preferably with a red light filter over the eye-piece).

Calculation.-Equimolecular amounts of phenol and phosphate are liberated when phenyl phosphate is hydrolysed. For each molecule of phenol of molecular weight 94 there is a molecule of phosphate containing one atom of phosphorus (P) of atomic weight 31 . Therefore, there are three times (approximately) as much phenol, by weight, liberated in a

* Determination of phosphate with aminonaphtholsulphonic acid. 
given time as there is phosphate expressed as P. The King-Armstrong phosphatase unit is defined as that amount of enzyme which liberates $1 \mathrm{mg}$. of phenol from phenyl phosphate. It can equally well be defined as that which liberates $\frac{1}{3} \mathrm{mg}$. P. And it is consequently necessary to multiply the amount of $P$ (mg.), liberated in the 15 minutes, by three to obtain a figure equal to the King-Armstrong unit. The units of phosphatase, in any determination, then, are equal to the mg. of phenol, or to three times the $\mathrm{mg}$. of $\mathbf{P}$ liberated by the hydrolysis of phenyl phosphate. This is equal to the phenol or phosphate in the test (which consists of that liberated by hydrolysis, plus that already present in the plasma (control) and the small amount of free phenol or phosphate in the buffer-substrate blank), minus the sum of the phenol or phosphate in the control and the blank. The $5 \mathrm{ml}$. of filtrate from test and control are equal to $0.2 \mathrm{ml}$. of plasma. To convert the units of phosphatase to $100 \mathrm{ml}$. of plasma (basis) it is necessary to multiply by 100 over 0.2 .

Phosphatase units per $100 \mathrm{ml}$. of plasma (or serum)

$$
\begin{aligned}
& =\frac{\text { Reading of Test }-(\text { Control }+ \text { Blank })}{\text { Reading of Standard }} \times 0.02 \times 3 \times \frac{100}{0.2} \\
& =\frac{\mathrm{T}-(\mathrm{C}+\mathrm{B})}{\mathrm{S}} \times 30 \text { (when read in a photo-electric colorimeter) } \\
& \text { or, }=\frac{\mathrm{S}}{\mathrm{T}}-\frac{(\mathrm{S}}{(\mathrm{C}}+\frac{\mathrm{S})}{\mathrm{B})} \times 30 \text { (when read in a Duboscq colorimeter). }
\end{aligned}
$$

The inorganic phosphate of the plasma or serum is that contained in the control.

$$
\begin{gathered}
\begin{array}{c}
\text { Inorganic } \mathrm{P} \\
(\mathrm{mg} .100 \mathrm{ml} .)
\end{array}=\frac{\text { Reading of Control }}{\text { Reading of Standard }} \times 0.02 \times \frac{100}{0.2} \\
=\frac{\mathrm{C}}{\mathrm{S}} \times 10 \text { (when read in a photo-electric colorimeter) } ; \\
\text { or } \frac{\mathrm{S}}{\mathrm{C}} \times 10 \text { (when read in a Duboscq colorimeter). }
\end{gathered}
$$

\section{Alkaline Phosphatase : Micro Method II *}

Test.-Quantities, $1 \mathrm{ml}$. each of buffer and substrate, are pipetted into a test-tube and warmed in a water bath at $37^{\circ} \mathrm{C}$. for 3 or 4 minutes ; $0.1 \mathrm{ml}$. of plasma or serum is added, stoppered, mixed, and kept at $37^{\circ}$ for 15 minutes. Seven per cent trichloroacetic acid, 2.9 ml., is added, the tube removed and shaken, and the mixture filtered or centrifuged.

Control.-The control is prepared by treating $2 \mathrm{ml}$. water and $0.1 \mathrm{ml}$. of plasma with $2.9 \mathrm{ml}$. of $7 \%$ trichloroacetic acid, mixing, and filtering.

Blank.-The blank consists of buffer and substrate, $1 \mathrm{ml}$. each, $0.1 \mathrm{ml}$. water, and $2.9 \mathrm{ml}$. of $7 \%$ trichloroacetic acid.

Standard. - The standard consists of the standard phosphate solution ( $1 \mathrm{ml} . \equiv 0.004 \mathrm{mg} . \mathrm{P})$, plus $1 \mathrm{ml}$. of $7 \%$ trichloroacetic acid.

Phosphate Determinations.-The standard, and $2 \mathrm{ml}$. each of the test, control, and blank are diluted with $3 \mathrm{ml}$. of water, and treated with $0.8 \mathrm{ml}$. of molybdate. They are well mixed and $0.2 \mathrm{ml}$. of stannous chloride added, and mixed again. The colours are read after 15 minutes. With a photo-electric colorimeter the zero is set with a reagent blank consisting of $4 \mathrm{ml}$. water, $1 \mathrm{ml}$. of $7 \%$ trichloroacetic acid, $0.8 \mathrm{ml}$. molybdate, and $0.2 \mathrm{ml}$. stannous chloride.

Calculation.-The $2 \mathrm{ml}$. of test and control represent $0.04 \mathrm{ml}$. of plasma, and, therefore, phosphatase units per $100 \mathrm{ml}$.

*Determination of phosphate with stannous chloride. 
$=\frac{\text { Reading of test }-(\text { Control }+ \text { Blank })}{\text { Reading of Standard }} \times 0.004 \times 3 \times \frac{100}{0.04}$

$=\frac{T-(C+B)}{S} \times 30$ (when read in a photo-electric colorimeter);

or, $\left.=\frac{S}{T}-\frac{(S}{(C}+\frac{S)}{B}\right) \times 30$ (when read in a Duboscq colorimeter)

Inorganic $P(\mathrm{mg} . / 100 \mathrm{ml})=.\left[\frac{\text { Reading of Control }}{\text { Reading of Standard }} \times 0.004 \times \frac{100}{0.04}\right.$

$=\frac{\mathrm{C}}{\mathrm{S}} \times 10$ (when read in a photo-electric colorimeter)

or, $\frac{S}{C} \times 10$ (when read in a Duboscq colorimeter)

\section{The Stannous Chloride Phosphate Method}

Stannous chloride is not as good a reducing agent for the colorimetric determination of phosphate as aminonaphtholsulphonic acid, but it yields much more blue colour from the same amount of phosphate. It is therefore preferred for minimal micro-methods. The colours

Time after adding $\mathrm{SnCl}_{2}$ (min.)

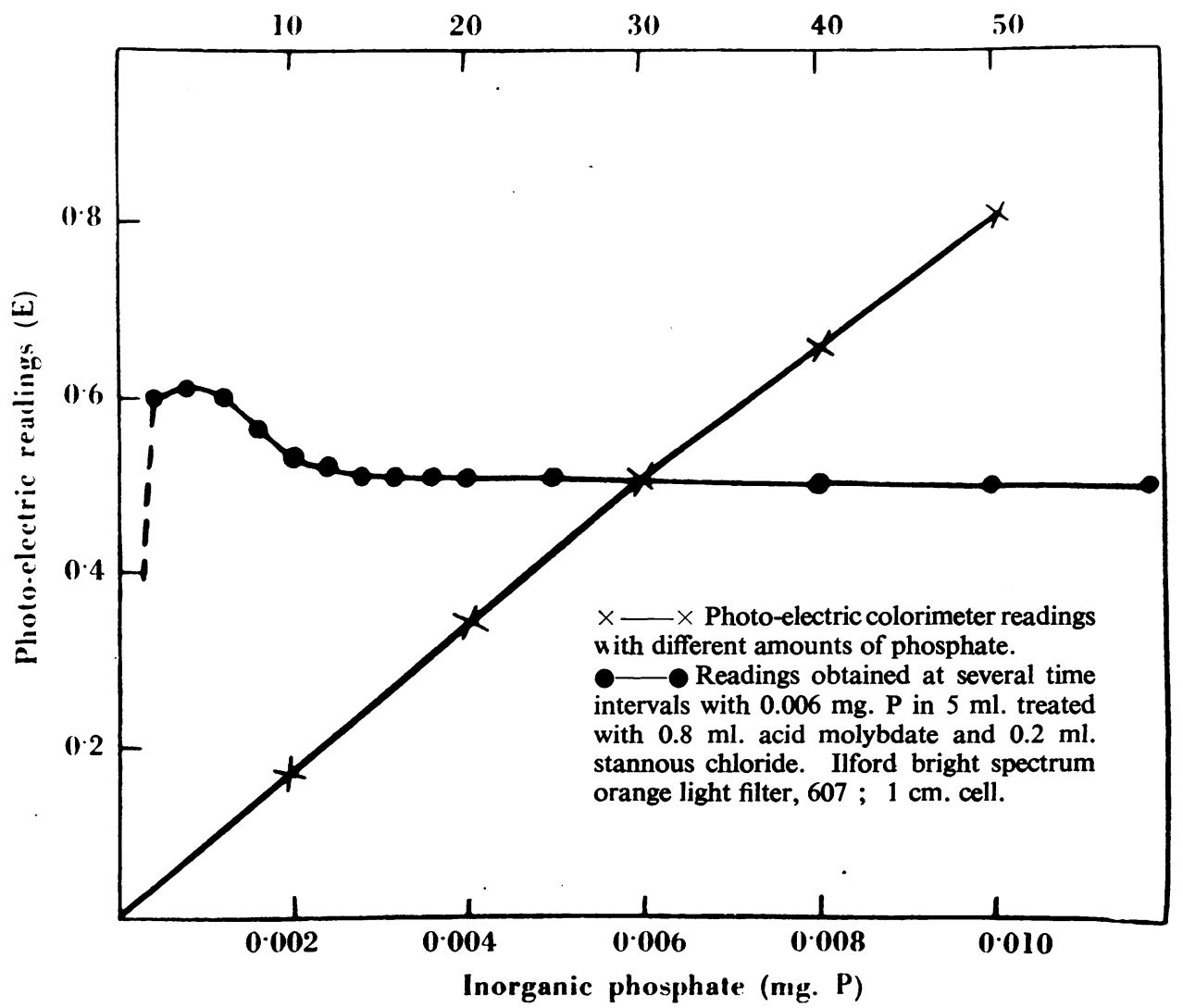

Fig. 1.-Proportionality of colour and rate of colour development with the stannous chloridemolybdate method for inorganic phosphate. 
produced with it may not always obey Beer's law (Bodansky, 1937). It is more sensitive to changes in the concentration of acid present than the photographic reducing agents, and there may be non-specific reduction of the molybdate if the mixtures are not well mixed before and immediately after adding the $\mathrm{SnCl}_{2}$ solution. But if the conditions of the test and the concentrations of reagents are carefully chosen, it is possible to obtain reproducible and proportional results (Fig. 1). The accuracy of the procedure is sufficient for most purposes.

\section{Results}

Alkaline Phosphatase.-Comparisons between these two phosphate procedures, on the one hand, and the phenol method of determining phosphatase on the other, have yielded results which agree very well. These are set out in Tables I and Il. It is apparent that with phenyl phosphate as substrate the same result, or nearly the same result, is obtained by all three procedures, and that it makes no difference whether phenol or phosphate is determined and taken as the measure of the enzyme activity. The errors are not greater than one might expect in comparing any two

TABLE I

Determination of Serum Alkaline Phosphatase by Phenol and Phosphate Methods

\begin{tabular}{|c|c|c|c|}
\hline \multirow[b]{2}{*}{ Case } & \multirow{2}{*}{$\begin{array}{l}\text { King-Armstrong } \\
\text { Phenol Method } \\
\text { (units } / 100 \mathrm{ml} \text {. } \\
\text { serum) }\end{array}$} & \multicolumn{2}{|c|}{$\begin{array}{l}\text { Phosphate Method } \\
\text { (Aminonaphtholsulphonic Acid) }\end{array}$} \\
\hline & & $\begin{array}{c}\text { Phosphatase } \\
\text { (units } / 100 \text { ml. serum) }\end{array}$ & $\begin{array}{c}\text { Inorganic P } \\
\text { (mg./100 ml.) }\end{array}$ \\
\hline $\begin{array}{l}\text { Normal adult } \\
\text { ", child } \\
\text { Rickets ", } \\
\text { ", } \\
\text { ", } \\
, " \\
, " \\
\text { ?", } \\
\text { ?epatitis } \\
\text {," } \\
\text {," } \\
\text {," } \\
\text {," } \\
\text { ", } \\
\text { Cirrhosis } \\
\text { Obstructive jaundice } \\
\text { Splenomegaly ", } \\
\text { Paget's disease } \\
\text { Prostatic carcinoma }\end{array}$ & $\begin{array}{r}7.0 \\
9.5 \\
9.8 \\
9.8 \\
13.0 \\
11.0 \\
36.5 \\
38.0 \\
43.5 \\
45.5 \\
57.5 \\
65.5 \\
67.5 \\
116.5 \\
7.0 \\
14.0 \\
14.4 \\
16.5 \\
19.0 \\
19.0 \\
20.5 \\
27.5 \\
28.0 \\
6.4 \\
12.0 \\
34.5 \\
46.5 \\
30.0 \\
56.0 \\
22.1\end{array}$ & $\begin{array}{r}6.3 \\
8.8 \\
10.0 \\
10.6 \\
12.7 \\
11.2 \\
32.5 \\
35.7 \\
40.5 \\
47.5 \\
60.0 \\
65.0 \\
63.5 \\
120.0 \\
6.0 \\
13.2 \\
15.0 \\
14.8 \\
17.5 \\
18.8 \\
21.4 \\
25.8 \\
27.5 \\
6.0 \\
11.5 \\
32.3 \\
47.1 \\
30.5 \\
53.2 \\
20.8\end{array}$ & $\begin{array}{l}2.9 \\
4.1 \\
3.6 \\
4.2 \\
4.3 \\
4.5 \\
3.5 \\
2.5 \\
2.0 \\
1.6 \\
1.8 \\
1.6 \\
1.8 \\
1.7 \\
3.2 \\
3.4 \\
5.2 \\
3.0 \\
3.5 \\
3.0 \\
3.6 \\
4.0 \\
2.8 \\
3.8 \\
4.1 \\
3.1 \\
2.9 \\
4.1\end{array}$ \\
\hline
\end{tabular}


TABLE II

Determination of Serum Alkaline Phosphatase by Phenol and Phosphate Method

\begin{tabular}{|c|c|c|c|}
\hline \multirow{2}{*}{ Case } & \multirow{2}{*}{$\begin{array}{l}\text { King-Armstrong } \\
\text { Phenol Method } \\
\text { (units } / 100 \mathrm{ml} \text {. serum) }\end{array}$} & \multicolumn{2}{|c|}{$\begin{array}{l}\text { Micro Phosphate Method using } \\
\text { Stannous Chloride }\end{array}$} \\
\hline & & $\begin{array}{c}\text { Phosphatase } \\
\text { (units } / 100 \mathrm{ml} \text {. serum) }\end{array}$ & $\begin{array}{l}\text { Inorganic P } \\
(\mathrm{mg} . / 100 \mathrm{ml} .)\end{array}$ \\
\hline $\begin{array}{c}\text { Normal adult } \\
\text {," ,", } \\
,, \\
,, \\
\text {,", } \\
\text { Normal child } \\
\text { Rickets ," } \\
\text {," }\end{array}$ & $\begin{array}{r}6.4 \\
8.2 \\
8.8 \\
10.0 \\
10.2 \\
15.2 \\
11.2 \\
12.8 \\
26.6 \\
40.0 \\
71.0\end{array}$ & $\begin{array}{r}6.2 \\
6.8 \\
9.3 \\
11.4 \\
9.0 \\
14.8 \\
12.0 \\
12.4 \\
27.5 \\
37.5 \\
66.5\end{array}$ & $\begin{array}{l}4.0 \\
3.2 \\
2.9 \\
3.3 \\
3.0 \\
5.6 \\
5.8 \\
4.0 \\
2.4 \\
1.3\end{array}$ \\
\hline
\end{tabular}

different colorimetric procedures. And when it is remembered that errors of measurement, dilution, and precipitation of protein by two different means are included with those due to the production of colours by two different chemical reactions, then it is seen that the agreement is all that can be desired.

The micro procedure (Method II) using only $0.1 \mathrm{ml}$. of serum, and stannous chloride as the reducing agent, is a useful modification where only small amounts of blood are available, as may frequently be the case in the investigation of infants. And there is no reason why the method should not be made still more minimal, with, say, $0.05 \mathrm{ml}$. of serum or plasma, by employing small test-tubes and colorimeter cells and cutting all quantities by half.

Inorganic phosphate results (expressed as $\mathrm{mg}$. $\mathrm{P} / 100 \mathrm{ml}$. of serum) for the same blood sera are included in the tables; these are the figures obtained from the controls in the phosphatase methods.

Acid Phosphatase.-It is perhaps worth pointing out that either of these modifications of the phosphatase determination can be applied to the estimation of acid phosphatase (Gutman and Gutman, 1940; King, 1951) just as well as to alkaline

TABLE III

Determination of Serum Acid Phosphatase by Phenol and Phosphate Methods (Aminonaphtholsulphonic ACID Procedure)

\begin{tabular}{cc|c|c} 
& \multirow{2}{*}{ Case } & \multicolumn{2}{|c}{ Method (units/100 ml. serum) } \\
\cline { 3 - 4 } & & Phenol & Phosphate \\
\hline Normal & 0.9 & 1.5 \\
", & 1.4 & 2.6 \\
Prostatic carcinoma & 3.9 & 4.5 \\
", & 8.3 & 7.1 \\
", & ", & 14.0 & 13.9 \\
& & 32.0 & 15.9 \\
\end{tabular}


phosphatase, if it is desired to carry out the estimations by means of phosphate determination instead of the usually used phenol determination. But it is necessary to employ an acetic acid buffer ( $p \mathrm{H} 4.9$ ) instead of the usual citric acid buffer, since the latter interferes with the molybdate procedures for determining inorganic phosphate. The mixtures of substrate, buffer (acetic), and serum are as above, the time of $38^{\circ}$ incubation is one hour, and the phosphate determinations as described. With the aminonaphtholsulphonic method we have obtained the type of agreement between it and the phenol acid phosphatase procedure (Gutman and Gutman, 1940; King, 1951) which is illustrated in Table III.

\section{Summary}

Two modifications of the King-Armstrong phenyl phosphatase procedure for serum alkaline phosphatase determinations have been described.

Since equimolecular quantities of phenol and inorganic phosphate are liberated in the hydrolysis of phenyl phosphate, it has been possible to substitute determinations of phosphate for those of phenol, which have hitherto been used.

In the first method $0.3 \mathrm{ml}$. of plasma or serum is employed, and the inorganic phosphate method of Fiske and Subbarow (1925) using aminonaphtholsulphonic acid as the reducing agent.

In the second method, which is a micro modification, $0.1 \mathrm{ml}$. of plasma or serum is used, and the stannous chloride-molybdate method of phosphate determination.

Results obtained by these "phosphate" procedures are in good agreement with those by the "phenol " method of determining phosphatase activity.

Determinations of the inorganic phosphate of the plasma or serum are included as part of the phosphatase determination.

\section{REFERENCES}

Bodansky, A. (1933). J. biol. Chem., 101, 93.

- (1937). Amer. J. clin. Path., 7, Tech. Suppl., 1, 51.

Fiske, C. H., and Subbarow, Y. (1925). J. biol. Chem., 66, 375.

Gutman, E. B., and Gutman, A. B. (1940). Ibid., 136, 201.

Jenner, H. D., and Kay, H. D. (1932). Brit. J. exp. Path., 13, 22.

King, E. J. (1951). Micro-analysis in Medical Biochemistry. 2nd ed. London.

- and Armstrong, A. R. (1934). Canad. med. Ass. J., 31, 376. 